\title{
Financial Crisis in the Euro-Zone and Moral Hazard
}

\author{
Hernán Ricardo Briceño Avalos \\ Graduate School of International and Area Studies, Hankuk University of Foreign Studies, Seoul, South Korea
}

Email address:

hrbricenoa@hotmail.com, b.hernanricardo@student.maastrichtuniversity.nl

\section{To cite this article:}

Hernán Ricardo Briceño Avalos. Financial Crisis in the Euro-Zone and Moral Hazard. Journal of Finance and Accounting. Vol. 4, No. 4, 2016, pp. 164-178. doi: 10.11648/j.jfa.20160404.12

Received: December 10, 2015; Accepted: April 16, 2016; Published: June 8, 2016

\begin{abstract}
The aim of this document is provide empirical evidences and theoretical knowledge about how the compelling current Sovereign Debt Crisis in the periphery Euro-zone countries was triggered in accordance with Moral Hazard theory, because the implicit and explicit externalization of risk cost for commercial financial institutions. Different from traditional working papers that concentrated only on weak macroeconomic fundamentals and contagion effects as the main origins of the previous financial crises. This research is dealing with the question how moral hazard problem in the Euro-zone periphery after the introduction of the Euro currency as a global competitor of the U.S.A. Dollar caused and/or nurtured their Fiscal and External unbalances. This after a short period of euphoria and wellbeing, with reduction of the interest rate and easily access of fresh capital to finance unprofitable and risky biased businesses without appropriate banking regulation; ending up in a vicious circle between weak banking system and fiscal imbalances. After assessing different economic and financial statistics from the Euro-zone, as the ratio Short Term External Debt/Foreign Exchange Reserve as a Moral Hazard index and Fiscal and External unbalances Accounts, making a comparison with North-core Euro countries. The first evidence is that the Sovereign Debt Crisis was originated in the awkward circle between weak financial system and implicit guarantees provided by negligent governments without financial regulation and supervision; while politicians differed necessary reforms as Fiscal Union.
\end{abstract}

Keywords: Moral Hazard, European Monetary Union, Sovereign Financial Crisis, Financial Crisis

\section{Introduction}

There are different factors that explain a financial crisis. Some researchers traditionally concentrated on the Fixed/Pegged Exchange Rate and overvaluation of the local currency, domestic credit expansion, high and persistent deficits in the Current Account of the Balance of Payments and Fiscal Accounts, high stock of Public Debt. These research including also external shocks, such as increasing of international interest rates or falling down of the Terms of Reference in Trade (TOR); and contagion effect (herd behavior). However, there are other factors that help understand better how financial crises were originated. Therefore, this document explore other sources of the current European Sovereign Debt Crises as Moral Hazard of the economic/financial and politic agents that allowed financial institutions (banks) externalize risk cost, combined with politic crisis, profligates and corruption in the so-called European periphery: Greece, Italy, Portugal, Ireland, and Spain (PIIGS).
The Moral Hazard is a behavior caused by asymmetric information in the financial markets, where the commercial financial institutions such as banks have better/more information than the regulator (financial supervisor) about transactions, efforts to avoid collapses and crisis in advance or ex ante (the so-called third generation of currency crisis model). Consequently, for the aim of this document Moral Hazard is defined as the awkward behavior of some economic agents and politicians in the European Monetary Union (EMU) in the last decade after the introduction of the Euro as a global currency. Initially, the introduction of this regional policy allowed them experiencing a sense of wellbeing boom for a short time in the early 2000 s, due to easy access credits with low interest that conducted toward an extremely hazardous indebtedness of financial institutions, taking high risk position increasing the ratio Short Term Debt/Foreign Exchange Reserve. This under the absence of appropriated financial regulation/supervision. Furthermore, some governments implicitly guarantee weak banks to borrow funds, allowing externalization of risk cost, creating a 
compelling vicious circle with the Public Debt.

Certainly, more of the scholars have concentrated on some economic variables disequilibrium (weak fundamentals) aforementioned, but ignoring the real and original causes of this turmoil the moral hazard incurred ex ante by some of the financial stakeholders. In this way, the basic research question addressed in this document is how the moral hazard problem incurred by financial institutions in the Euro-zone periphery in the last decade caused and/or nurtured the current Sovereign Debt Crisis. This main research question will allow understand how the introduction of the European Monetary Union (EMU) and the Euro as a global currency and competitor of the U.S.A. Dollar by the end of 1990 years, nurtured or triggered the nowadays European Financial Crisis.

The organization of this document, in the next section (II) the basic literature reviewing about how the Moral Hazard problem has been empirically presented in the previous financial crises in Latin America, East Asia, Russia, United States of America and other countries. In the third section we concentrate on the theoretic framework based on Asymmetric Information theory and Moral Hazard. The fourth section intends to assess the relationship and causality between theoretic moral hazard definition and the empirical financial problems in the last years in the European Monetary Union. The conclusions and main economic policy implications is provided in the last section.

\section{Literature Review}

This section is based on academic research about Financial Crises, emphasizing moral hazard as the main factor that triggered financial crises under the absence of suitable regulation, liberalization, wrong Central Banks interventions, government bailouts of financial institutions that create a vicious circle between them, politic instability and other related activities, leading financial institutions (banks) to externalize risk cost. For instance, United States of America (2007), Argentina (2000), Brazil and Russia (ending 1990s), Asia and Mexico (1997/98 and 1994/95, respectively) and one decade before Latin America (Chilean) financial crises (The Lost Decade, 1980s). The first case was North American mortgage crisis under liberalization (deregulated) policies, "created not only by all those terrible people on Wall Street who took risks and ruined the economy because of they were greedy, but also by the real state bubble, playing the Central Bank a big role in its formation; therefore, it is necessary more formal checks and balances to prevent the Federal Reserve taking large risks" (Allen and Carletti, 2009). Let us not forget deregulation started in 1980s with Reagan's administration, followed Mr. Bush, Mr. Clinton and Mr. Bush (child), without strict financial regulation and supervision; especially, financial derivatives and new sophisticated financial instruments, making finance industry the most profitable sectors.

In accordance with De Soto (2011), based on the property rights theory and good rule of law system, it has been very difficult to identify the owners of 60 percent of the Real State mortgages in the USA, at the same time it has not been established a regulation to avoid them from toxic documents ${ }^{1}$. Undoubtedly, the combination of both situations have caused that some private banks and investors felt into moral hazard behavior, taking advantage under implicit government financial support (for financial system) and externalization of risk cost.

Another case of financial crisis along with politic crisis and corruption is Argentina. Carlos Menem was elected President in 1989, under economic debacle, hyperinflation, recession and high unemployment, etc., and started structural adjustment program: tax reform, privatizations of public enterprises, trade and financial liberalization during the $1990 \mathrm{~s}^{2}$; as well as the adoption of the Currency Board System enacted the Convertibility Law in $1991^{3}$. At the same time, one of the Argentina chronic problems was corruption of politics and public officials, that made Currency Board System failed. It was different from Hong Kong, which is working very well under Fiscal discipline (Chiu, 2001) ${ }^{4}$. Furthermore, corruption restricted international loans for this country. Finishing the period of Menem, after financial crisis in Russian (1998) and Brazil (1999) $)^{5}$, Argentina entered in a prolonged recession by the third quarterly of 2000 and unemployment rate increased faster. In the middle of economic crisis De la Rua was elected President and got International Monetary Fund assistance.

In October 2000, the Deputy-President Carlos Alvarez resigned over the La Rua's decision did not replace two cabinet members linked with a Senate bribery scandal, contributed to political instability and financial panic that triggered financial crisis. After passing law to cut budget in January 2001, the Minister of Finance Cavallo resigned and later the President De la Rua. Then the Congress pointed out the San Luis Governor Rodriguez Saa, December 2001, as interim President, and announced a new economic plan: a) suspension of Public Debt payments, b) new job creation program, c) a new unconvertible currency. However, political and economic problems continued and the Congress chose Peronist Senator Duhalde to complete 2003 as President. It was announced the Currency Board ending, its devaluation in 29 percent for major foreign commercial transactions, with the adoption of the Floating Exchange Rate for all other transactions, started financial crisis (Hornbeck, 2002).

The Brazilian financial crisis (1999) showed the carelessness of the government to regulate and supervise appropriately the baking system, after starting the process of liberalization with a fixed exchange rate. This was a result of the Real Plan implemented after Cardoso had been elected President in 1994 (second period), who adopted free market policies (Franco, 1995). Indeed, under Fixed Exchange rate

\footnotetext{
1 De Soto, Hernando (Dec. 02, 2011). International Herald Tribune Newspaper. 2 According to "Washington Consensus" Recommendations.

3 Hornbeck, J.F. The Argentine Financial Crisis, 2002.

4 Chiu, Priscilla (2011). Hong Kong Experience in Operating the Currency Board System.

5 In January of 1999, Brazil devalued its domestic currency (Real) and damaged Argentina exports in 30 percent.
} 
the model needs capital influx to accumulate Foreign Exchange Reserve to defend the pegged exchange rate. This results in a high international Debt US\$ 230 billon, the second largest in the world, with a total net Foreign Direct Investment flow of US\$ 60 billion since 1994, stimulated by the liberalization and scarce regulation. The portfolio flows during 1997 and 1998 were US\$ 71 billion in, and US\$ 68 billion out; as well as portfolio investment (mixture of equity and bond purchased $)^{6}$. At the same time tariff liberalization allowed increasing imports of goods and services, increasing Deficit in the Current Account (BoP), reached 4.5 percent of GDP, and high demand for U.S.\$ to finance imports. Additionally, we have the economic growth in Latin American countries in 1990s as a period of euphoria that led banks met credit demand from private sectors easily, supported by foreign capital influx, banks detrimentally preferred returns over liquidity, maintaining low reserves and adopting more speculative posture becoming carelessness. This also occurred in Mexico (1994) and Korea (1997).

One year after triggering financial crisis in Asia, we had the Russian Crisis (Summer 1998); as a consequence of political uncertainty and financial liberalization without regulation, as part of its socioeconomic and politic transformations from centrally planned economy lead development toward private sector market based decisions. The liberalization of different sectors was difficult because these were part of the State structure without regulation for many years, accumulating deficiency and losing competitiveness (UNCTAD, 1998). Starting liberalization of the financial sector without appropriate regulation and weaken institutions, the private property was unfairly concentrated in few managers, at the same time neither have the correct incentives nor sufficient capital in order to deal with transformations and necessary modernizations; the classic Agency-Principal problem. The straight monetary policy with high interest rate and lack of supervision in the financial market, bolstered the financial crisis in this transition economy due to the fact that allowed a huge inflow of external capital (equities), long run and short terms capitals, it was registered speculative financial operations under externalization of risk cost, with implicitly government guarantees. Furthermore, the Public Sector was characterized by scarce of transparency and irregularities, developed reforms on Public Spend and collecting taxes. Last but not least, the heavy retirement pension fund deficit was one of the factors that nurtured fiscal imbalance (UNCTAD, 1998).

Meanwhile, the 1997 Asian Financial Crisis was caused not only by traditional macroeconomic disequilibrium factors and weak fundamentals (Zhuang and Dowling, 2002), but also by Moral Hazard problems (Third Generation of Currency Crisis Model), as well as political uncertainty under changes in governments ${ }^{7}$, political transitions and

6 Most of it is owed to commercial banks, mainly European.

http://www.twnside.org.sg/title/brazil-cn.htm

7 Korea and Thailand changed governments since the onset of the crisis, a new President was elected in Philippines, and the current Indonesia President was weakening health. Radelt and Sachs (1998). deregulation of the financial system. Therefore, there was presented high indebtedness implicitly supported by governments that helped triggered the financial crises; private investors got financial funds to invest without suitable supervision in unsustainable sectors (Radelt and Sachs, 1998). Furthermore, these financial institutions increased awkward businesses used a mismatched maturity method: borrowing from international markets on a short-term basis and investing in Association of Southeast Asian Nations (ASEAN) markets on a long-term basis (Kyong ju Kim, 2006), for example, in Thailand and Indonesia.

High levels of capital inflows, especially short-terms borrowings in 1990s (Cipollini and Capetanios, 2006), place new pressures on underdeveloped and lack of technical supervision on financial system, commercial banks and Central Banks, institutional changes generally cannot keep pace with the high level of international flows; which in turn generates conditions for excessive risk taking, poor banking judgment, and even outright frauds ${ }^{8}$. Consequently, the easy accessibility of financial funds; especially, by big enterprises and business groups (Korean chaebols) supported by policy influences led invest in risk sectors because of risk cost externalization. Additionally, some of them were more interested in real property sector (building); tradable sectors were less interesting and lost competitiveness. Because one indicator to measure how increases indebtedness risky as a part of moral hazard is the ratio Short-Term Debt/Foreign Exchange Reserves, it had increased quickly, especially, South Korea and Thailand, the last years before financial crisis.

Another example of inappropriate financial regulation, under the adoption of liberalization policies was Mexico (1994-95), because of unrestrained financial and commercial liberalization policies adopted since the decade of 1980 s. This produced huge capital inflows without suitable regulation and supervision by the government, especially after the incorporation of Mexico to the General Agreement of Trade and Tariffs in 1986 (Licona, 2011). This allowed some financial institutions felt in Moral Hazard with high indebtedness and riskiness, monetary reserve requirements of the banks were eliminated, there were no capitalization rules based on market risk costs, lead increasing the default portfolio, expansion of Central Bank credit in 1994 as a last resort lender and forming price-asset bubbles. "The unseemly attraction of foreign resources, the liquidation of large amounts of government debt, and moral hazard nurtured an increasing in the private aggregate demand that contributed to the rapidly rising Current Account Deficit" (Gil, 1997) 9 .

Different factors contributed to increase the amount of credits such as reduction in Public Debt, the phenomenal international availability of securitized debt, poor borrower screening and credit-volume excesses; moreover, moral hazard was increased by unlimited backing of bank liabilities (Gil, 1997). Indeed, all these factors contributed directly the externalization of risk costs for financial investors. There

8 Ibid.

9 The Origin's of Mexico 1994 Financial Crisis. The Cato Journal. 
were over expectations in Mexican economy, just it signed the Free Trade Agreement (FTA) with United States of America and Canada (NAFTA), its accession to the Organization Countries for Economic Development (OCDE), and the good performance of Latin America economies in the first lustrum of 1990s. Finally, other political event that triggered this financial crisis was the assassination of a presidential candidate in March, 1994.

In this way, the Deficit in the Balance of Trade rose near 6 percent of the Gross Domestic Product, about 81 percent was explained by the rising in private investment, which was basically directed into unprofitable ventures, contributing to the unsustainability of the Current-Account Deficit. But this was a result also of the hard Foreign Exchange Rate policy (Licona, 2011) developed under the President Salinas (19881994). For instance, some of those undertakings were highly leveraged toll roads, unrecoverable home mortgages, or credit unions that invested with low or negative returns financed through the development banks. Some of the credits went to finance nonexistent enterprises or the hugely levered acquisition of bank shares and non-collateralized loans ${ }^{\mathrm{ii}}$.

One decade before (1980s), Latin American (Peru, Chile and Bolivia) suffered the Debt Crisis, the absence of appropriate supervision, increasing international liabilities of private sector and wrong financial funds allocation. One audit report published by the World Bank's Operations Evaluation Department on Chile structural adjustment loans highlighted that the lack of prudential supervision of financial institutions in increasing the economy's vulnerability led to collapse (World Bank, 1999a, p.2) Other factors were overvaluation of the Real Exchange Rate under Chilean fixed regimen, booming in the real state sector, high Current Account Deficit of Balance of Payments, triggered by external shocks, like the increasing of the international interest rate caused by the USA monetary policy contraction and the Terms of Trade felt for Latin American.

In the first half of 1980's, Chile suffered financial crisis, Chilean Private Pension Fund (AFPs) and some broken private banks were bailed out by the government (Central Bank), through their nationalization. Both financial rescuing operations for long years have been part of the Chilean Fiscal Deficit that received the name of socialization of the Debt, its cost was more than 2 percent of the GDP, US\$ 4 billons (Larrain and Vergara, 2000) $)^{\text {iv }}$. It is also fair to point out that according to its powerful, presence and participation in the political decisions, the military sector still keeping in the Public Pension Fund with the aim to prevent them from future financial crisis. This is part of the Moral Hazard problem because of some sectors near government decisions are taking advantage regarding others.

In short, these factors were part of the Moral hazard behavior because of externalization of risk cost for commercial financial institutions (banks) under political explicit or implicit- support defined in the introduction were presented not only in the previous financial crises, but also in the current Euro-zone Sovereign Debt Crisis (Table 1).

Table 1. Causes or Factors that Triggered Financial Crisis (1980-2000s).

\begin{tabular}{|c|c|c|c|c|c|c|c|c|}
\hline Factors: & $\begin{array}{l}\text { Argentina } \\
2001\end{array}$ & $\begin{array}{l}\text { Brazil } \\
1999 \\
\end{array}$ & $\begin{array}{l}\text { Russia } \\
1998 \\
\end{array}$ & $\begin{array}{l}\text { East Asia } \\
1997\end{array}$ & $\begin{array}{l}\text { Mexico } \\
1994\end{array}$ & $\begin{array}{l}\text { Chile } \\
1982 \\
\end{array}$ & $\begin{array}{l}\text { U.S.A } \\
2007\end{array}$ & $\begin{array}{l}\text { Euro } \\
\text { Zone }\end{array}$ \\
\hline Fixed Exchange Rate Regimen & Yes & Yes & Yes & Yes & Yes & Yes &.-- & Yes \\
\hline Over valuation of Exchange Rate & Yes & Yes & Yes & Yes & Yes & Yes &.-- & Yes \\
\hline High Public Debt and Fiscal Deficit & Yes & Yes & Yes & Not & Yes & Yes & Yes & Yes \\
\hline $\begin{array}{l}\text { Current Account Deficit and External Sector } \\
\text { Problems }\end{array}$ & Yes & Yes & Yes & Yes & Yes & Yes & Yes & Yes \\
\hline Private Sector Over Indebted & Not & Yes & Yes & Yes & Yes & Yes & Yes & Yes \\
\hline Boom in the real state sector & Not & Not & Not & Yes & Not & Yes & Yes & Yes \\
\hline Contagion Effects & Not & Yes & Yes & Not & Not & Not & Not & Yes \\
\hline $\begin{array}{l}\text { Scarce Accountability and Institutional } \\
\text { Regulation Failure: Moral Hazard }\end{array}$ & Yes & Yes & Yes & Yes & Yes & Yes & Yes & Yes \\
\hline High expectations on economic successful & Not & Yes & Not & Yes & Yes & Not & Not & Not \\
\hline Global Currency (US\$ or Euro) & Not & Not & Not & Not & Not & Not & Yes & Yes \\
\hline
\end{tabular}

Source: Different international studies about financial crises.

\section{Asymmetric Information Theory and Applied Moral Hazard Definition}

Moral Hazard is a result of Asymmetric Information problem presented in market interactions. Imperfectly informed markets with one side better informed than other are markets with asymmetric information (Varian, 2000); therefore, the neoclassical paradigm of perfect competition markets does not exist. In this way, there are prominent researchers that have been even laureate with the Nobel Prize in Economics in this area. For instance, George Akerlof ${ }^{10}$, Michael Spence ${ }^{11}$ and Joe Stiglitz ${ }^{12}$ originated the Theory of Information in modern Microeconomics courses. This Asymmetric Information Theory has been applied by economic practitioners like financing and banking, insurance services, businesses, labor markets; however, not enough times in order to assess the origins of Financial Crises: Asymmetric information between financial institutions

10 Akerlof, George (1970). The Market for Lemons: Quality Uncertainty and the Market Mechanism.

11 Spence, Michael (1973). Job Market Signaling and Book Market Signaling.

12 Equilibrium in Competitive Insurance Markets: An Essay on the Economics of Imperfect Information (1976) 
(banks) and the regulator (government), which originated the classic problem of Agent - Principal.

Akerlof analyses a special market of goods (second hand autos) where sellers have better information about quality of the products that they are offering regarding buyers, this market needs to be regulated in order to separate i) appropriate second hand autos and (ii) wrong second hand autos (lemons). Otherwise, if buyers cannot observe quality of product, unscrupulous and irresponsible sellers can offer and sell wrong second hand autos (lemons) as the high quality ones. "It should also be perceived that in these markets social and private returns differ, and in some cases observations make increase the social welfare of all parties; or private institutions may arise to take advantage of the potential increases in welfare which can accrue to all parties"13.

Spence focused on labor market saying that according to asymmetric information, high productive workers may get education exactly as a signal of their high productivity; therefore, he has developed the "signaling theory" that differs in the treating from moral hazard approaches. Moreover, Stiglitz (and Rothschild) about adverse selection as a result of asymmetric information problems. These authors considered that the insurance businesses where companies do not have information ex ante about the risk of their potential clients, while clients know well about themselves and their own effort to avoid accidents. In this way, under asymmetric information these authors consider two kinds of equilibriums: pooling and separating. In the first, all individuals buy the same amount of insurance, in the other, clients purchase different contracts. One of the conclusions is asymmetric information markets need to be regulated, especially the financial market. Consequently, Stiglitz has developed economic theories about hypothesis of efficiency on financial markets (with Grossman, 1980) and credit markets (with Weiss, 1981).

There are different Moral Hazard ways, based on risk costs externalization, which is assumed detrimentally by innocent bystanders (Mack, 2011) ${ }^{14}$. This topic has been applying in Financial, Macroeconomics and International Economics research, under the same meaning of reaction behavior of economic agents because of special incentives to becoming neglectfulness and increase the risk of loss (Varian, 2000). For instance, Akerlof and Romer (1994) and Radelt and Sachs (1998), understand that moral hazard related financial crisis arises because the banks are able to borrowing funds on the basis or implicit and explicit public guarantees (externalization of risk cots). For the both last authors coincidentally, "if banks are undercapitalized or underregulated, they may use these funds in overly risky or even criminal ventures".

Furthermore, Akerlof and Romer argued that the "economic of looting" in which banks use their state backing

13 Akerlof, George (1970). The Market for Lemons: Quality Uncertainty and the Market Mechanism.

14 Hillman (1992) pointed out that limited liabilities, similar to externalize risk cost, is very inefficient. to purloin deposit, is more common than is generally perceived and played a large role in the United States of America savings and loan crisis. Krugman (1998) argued that the 1997 Asian Financial Crisis is a reflection of excessive gambling and stealing by banks that gained access to domestic and foreign deposits by virtue of state guarantees ${ }^{15}$. Another support is the economic theoretic models about financial crisis. For instance, according to Basu (2009), who builds a rational expectation microeconomic model about why the local crisis escalated into a general freeze in credit flows. The author included a risk of default, there is the probability $p$ that the entire loan will repaid and the probability $1-p$ that the loan will not be repaid; where $p$ $(0<p<1)$ depends on different factors, as banking regulation and supervision. With appropriate banking regulation and supervision it is hopefully that the $p$ increasing. Another model was developed by Diamond and Dybving (1983), which provides a mathematical statement to explain how a commercial financial institution with long maturity assets (businesses, investors and mortgages loans offered) and short-maturity liabilities (public deposits which can be withdrawn at any time) may be highly unstable for financial system. It can help us understand bank runs and consequently financial crisis. Furthermore, according to Roubini "no attempt at understanding the financial crisis of 2008-09 can be made without also considering the intellectual canvas against which it proceeded, one that long championed the innate virtues of markets efficiency, financial innovation and financial market opening, literally as ends in themselves". ${ }^{16}$ In this way, he predicted in advance the U.S.A. mortgage crisis based on past financial crisis experiences.

Following Holmstrom (1979) we can represent an asymmetric information model in formal terms, in which one unrealistic feature is the assumption that agent or financial institution (bank) chooses their efforts $a$, having the same information as the principal or regulator, which means that before anything about the state of the nature $(\theta)$ is revealed. In the situation that the principal or regulator observes only the outcome $x, s(x)$ denote the share of $x$ that goes to the agent and $r(x)=x-s(x)$ denotes the share of the outcome that goes to the principal (regulator). It is assumed that both parties agree on the probability distribution of $\theta$ and that the agent chooses $a$ before $\theta$ is known. In this case (constrained) Pareto optimal ${ }^{17}$ sharing rules $s(x)$ are generated by the follow mathematical program (1), in which $G(x)$ is the principal or regulator's utility function, defined under outcome $(\mathrm{x})$, which represents the interests of a society section, and $H(x, a)$ is the agent or (private) financial institution's utility function (part of the society), defined also over outcome (x) and efforts (a).

\footnotetext{
15 Radelt and Sachs (1998). The Onset of the Asian Financial Crisis. (Cited in) 16 Delimatsis, Panagiotis (2009). Financial Services Trade after Crisis (cited in). An additional review of Roubini's point of view has been commented by Stephen Mihn in her "The New York Times" column: http://www.nytimes.com/2008/08/17/magazine/17pessimistt.html?pagewanted=all

17 "Pareto optimal": situation in which is not possible that somebody (or one of the parties) improves its welfare condition without impoverish the other (part)
} 


$$
\begin{aligned}
& \text { Max: Social welfare: } W\{G(r(x)), H(s(x))\} \\
& \qquad \text { Max } E\{G(x-s(x))\} \\
& \text { subject to } E\{H(s(x), a)\} \geq H \\
& a \in \operatorname{argmax} E\left\{H\left(s(x), a^{\prime}\right)\right\}
\end{aligned}
$$

In this way, we can establish a social welfare function $W$ based on regulator and financial institutions utilities, but after reordering the functions we can obtain the same results by maximizing the expected welfare function of the Regulator (2), in accordance with the regulator utility function based on observed results $(x)$, discounted the utility of financial institutions. There is a negative relationship between regulator's utility and outcome taken by the commercial financial institutions (trade off); however, both formed the social welfare (W). The constraint (3) guarantees that the agent or financial institution (bank) gets a minimum expected utility $H$ attained via the financial market or negotiation. The argmax denotes the set of arguments that maximize the objective functions, this constrain reflects the restriction that the principal can observe $x$ but not $a$. If he also could observe $a$, a forcing contract to internalize cost risk could use to guarantee that financial institution (agent) selects a proper action or effort even when $s(x)$ is chosen to solve the first restrictions ignoring the third. Let $z$ be the signal about $\theta$ which the agent or commercial financial institution observes prior to choosing $a$, so that this choice becomes a function $a(z)$, as before we suppress $\theta$ and write $f(x, y, z, a)$ for the joint density function, where $y$ is some additional information observed by both parties. The best sharing rules $s(x, y)$ can be determined solving the program:

$$
\operatorname{Max} \int G(x-s(x, y)) f(x, y \mid z, a(z)) p(z) d x d y d z
$$

Where $G(w)$ is the principal's utility function defined over wealth $(\mathrm{w}=\mathrm{x}-\mathrm{s})$ alone, subject to:

$$
\begin{gathered}
\int U(s(x, y)) f(x, y \mid z, a(z)) p(z) d x d y d z- \\
\int V(a(z)) p(z) d z \geq \overline{H,}
\end{gathered}
$$

$a(z) \in \operatorname{argmax} \int U(s(x, y)) f\left(x, y \mid z, a^{\prime}\right) d x d y-V\left(a^{\prime}\right), \forall z .(7)$

Here $f(x, y / z, a)$ is the conditional density function of $x$ and $y$, given $\mathrm{z}$ and the action $a$, and $p(z)$ is the marginal density of $z$. Letting $u(z) p(z)$ be the multiplier function for the second equation and $\lambda$ the multiplier for the first restriction, pointwise gives the characterization:

$$
\frac{G^{\prime}(x-s(x, y))}{U^{\prime}(s(x, y))}=\lambda+\frac{\int \mu(z) \cdot f a(x, y \mid z, a(z)) p(z) d z}{\int f(x, y \mid z, a(z)) p(z) d z}
$$

The second term on the right side of this equation (8) indicates a deviation from a first best solution; consequently, under asymmetric information the society does not reach Pareto optimum, being necessary to establish a deductible in order to internalize the risk cost of the financial institutions.

In the context of the Principal-Agent relationship, the Agent (bank) provides a productive input called effort $(a)$ in order to do not over taking risk positions, that cannot be observed by the Principal (Regulator) directly; indeed, the results relate to a very specific kind of imperfect of the agent's actions. Therefore, the Principal (Regulator) does not know to what extent a social contract has been satisfied by the Agency (banks). Therefore, the bank uses their authority only for their own benefit (selfishness) rather than take into in Regulator's considerations, which represent the social interests, their financial creditors and public depositors; indeed, there is a clear disagreement between both kinds of institutions. This causes the modification of the probability distribution function of outcome $\boldsymbol{x}$, identified mathematically in terms of continuous time by the area under the first integral wealth function of the program (equation 5).

However, following Jehle and Reny (2000) we can establish a model in which assess how commercial Financial Institutions (Agents) can be less concerned in accordance with financial support of The Principal that led them to externalize risk costs; unfortunately Regulatory Institution cannot observe the efforts $(a)$ that Private Financial Institutions are doing in order to manage public funds (depositors) appropriate. In this way, the Principal must structure their policies so that by themselves induce the Agents to take an appropriate level of care by internalizing risk costs. When a Principal has a stake in the action taken by an Agent, but the Agent's action cannot be observed by the Principal, the situation is said to involve moral hazard. The Principal-Agent problem is for the Principal to design an incentive scheme so that the Agent (Commercial Financial Institution) takes an appropriate action ${ }^{18}$. To simplify we can establish a model in which exists the Regulator and only one Financial Institution, this last can incur in losses resulting in a varying amount of loss $L$, ranging from 1 through $L$ monetary units; depending on the severity of the risky financial operation. It is possible that the loss has been avoided wholly $(L=0)$. Under the assumptions:

(i) The probability of incurring in a risk operation resulting in losses of $1 €\{0,1, \ldots \mathrm{L}\}$ is given by the $p(a)>0$, where $a$ is the action or amount of effort exerted toward safe financial operations by the Agent; of course the probability $(p)$ is affected by the such efforts. For each fixed effort $a$, we have:

$$
\sum_{l} \pi_{l}(a)=1
$$

(ii) There are only two possible effort levels for the Financial Institutions or Agent, $\mathrm{a}=0$ denote low effort and $a$ $=1$ denote high effort.

(iii) Higher effort by the financial institution to reduce risky financial operations result in lower likelihood that they will have serious financial losses L, avoiding costly financial crisis in the society. So, the best policy for regulator differs and depends on whether it wishes to induce the commercial financial institutions to choose high or low effort to avoid taking risky and awkward financial operations by

18 Jehle, Geoffrey and Reny, Philip (2,000). Advanced Microeconomic Theory. The Addison-Wesley. 
internalizing the risk cost. Unfortunately, under asymmetric information that use to be in the financial markets, we have Paretto-inefficient outcomes because of the fact that there is a high cost for the regulator when intends to induce high effort $(a=1)$ of financial institutions (banks) to avoid turmoil.

\section{Causes of Periphery Euro-Zone Crisis}

Few authors consider irresponsibility of economic agents (governments) over spending and making risky investments, under externalization of risk cost. Consequently, one of the results was over indebtedness with foreign creditors under free interest rate, especially in Short Terms. Sometimes private sector was guaranteed by governments to develop or bailout special sectors or enterprises ${ }^{19}$. However, the difficulties of the EMU had existed before its introduction.

\subsection{EMU's Origins and Moral Hazard}

It had not existed previously a serious assessment (ex-ante) about sustainability of EMU. The motivations were more politics; their promoters did not take care about different economy characteristics among countries. The introduction of Euro led losing Nominal Exchange Rate Anchor and monetary political tools of each Central Bank for adjusting against external or domestic shocks, which was assigned to the regional European Central Bank. In this way, the interest rate has the aim to maintain the average stability of the Euro-zone, rather than respond to the conditions of a specific country (Glick, 2012) ${ }^{20}$, to reach a particular goal. Furthermore, political leaders postponed Fiscal Union, with the aim to not lose political sovereign and not lose presence in the World Economy. Different Budgets require different financing in a region where some members have very low tax revenues; consequently, they had been financing spending with borrowings from banks by issuing sophisticated financial instruments.

Another factor taken for granted was the commercial openness intensity. One country with different characteristics should issue its own currency (Mundell, 1961), keeping Flexible Exchange Rate; contrary what happened in the Eurozone $^{21}$. Therefore, in the context of the current EMU, countries by themselves cannot retain the ability to restore or gain national competitiveness by devaluing or depreciating their own currencies, because they do not exist. Meade (1957) argued that the conditions for a common currency did not exist in Western Europe because the lack of labor mobility; consequently, a system of Flexible Exchange Rates would be more effective in promoting Balance of Payment

\footnotetext{
19 Under industrialization policies to develop special sectors such as microchips, carmakers, heavy chemical industry in South Korea (1997) under the governmentled-economy oriented development model. Other example was the Industrial Substitution Import models in Latin America (1970 and 1980 years).

20 According to "Theory of Optimal Currency Area" a common currency is appropriate for countries with: (i) similar shocks and business cycles, (ii) high trade integration, (iii) internal labor flexibility, and (iv) Fiscal policy flexibility (Mundell, 1961).

21 Mundell, Robert (1961). "A Theory of Optimum Currency Area”.
}

equilibrium and internal stability ${ }^{22}$. Under different labor market structures, with different unit labor costs, rigidity regulations and different intensity of labor mobility, it could be possible that they have problems in the salary and prices flexibility, caused losing of competitiveness and serious unemployment problems. "Real unit labor costs related to major trading partners (a rough measure of national competitiveness) are moving against some of the poorer Southern countries of the Euro zone, Italy in particular; almost similar with United Kingdom" ${ }^{23}$. Ireland, Greece, Spain and Italy showed the highest increasing of Labor Unit Cost, while in Germany this indicator was reducing.

\subsection{Moral Hazard Index}

Recently some authors have considered moral hazard behavior as the main factors of current European Sovereign Debt Crisis (third generation models). They believed that the current crisis was fundamentally caused by profligate and irresponsible behavior by governments, politicians and individuals in the Euro Zone periphery. "Let's call this the local cause point of view: Government Deficits and Debts in the periphery were so large that once the Great Recession (2008-09), investors lost confidence in the ability of these countries to remain solvent. So they tried to dump the bonds from those countries, triggering the crisis" ${ }^{24}$. One of the first index assessed is the ratio Short Term External Debt (International claims - up to and including one year) ${ }^{25}$ between the Foreign Exchange Reserve ${ }^{26}$ in absolute terms, which provides information about the profligacy indebtedness of one country without appropriate guarantee in Foreign Exchange Reserve. This indicator was used before to assess Asian Financial crisis in an Early Warning Model by Zhuang and Dowling (2002). On contrary, sound Foreign Exchange Reserve management is important because increase a country's overall resilience to shocks, improve the ability to respond effectively to financial crisis and reduce financial and reputational costs ${ }^{27}$.

This was associated with the Euro adoption that produced interest rates falling only in the early 2000 s, a brief surge in confidence as institutions and false sensation of risk reduction. The incomes of periphery were expected to converge toward northern core economies, exacerbated the expectation of economic improvement and future wealthfare, spending beyond their own means. Monetary policy

22 Mundell, Robert (1961). "A Theory of Optimum Currency Area” (cited in).

23 Jones, Erick (2009). "The Euro and the Financial Crisis".

24 ("EZ periphery": Greece, Portugal, Ireland and Spain. Italy has not really been accused of such behavior, it seems generally accepted that it is much more the victim of contagion rather than the cause of the crisis). http://streetlightblog.blogspot.com/2011/09/what-really-caused-eurozone-crisispart.html

25 Bank of International Settlements (BIS), statistics.

26 Total reserves comprise holdings of monetary gold, special drawing rights, reserves of IMF members held by the IMF, and holdings of foreign exchange under the control of monetary authorities. The gold component of these reserves is valued at year-end (December 31) London prices. World Bank.

27 International Monetary Fund (2000). Guideline for Foreign Exchange Reserve Management. 
became more expansionary, causing reduction of the interest rate, increasing domestic demand, bidding up the price of no tradable goods to tradable as the real state sector, attracting more investment in the no tradable sector with less productivity, and increasing the rates of wages relative to productivity. "The single monetary policy of the Euro-zone was too loose for the countries which enjoyed the temporary biggest boom and accentuated their inflation and competitiveness losses; consequently, paradoxically PIIGS countries have become increasingly uncompetitive since adopting the Euro" (Dadush, 2010).

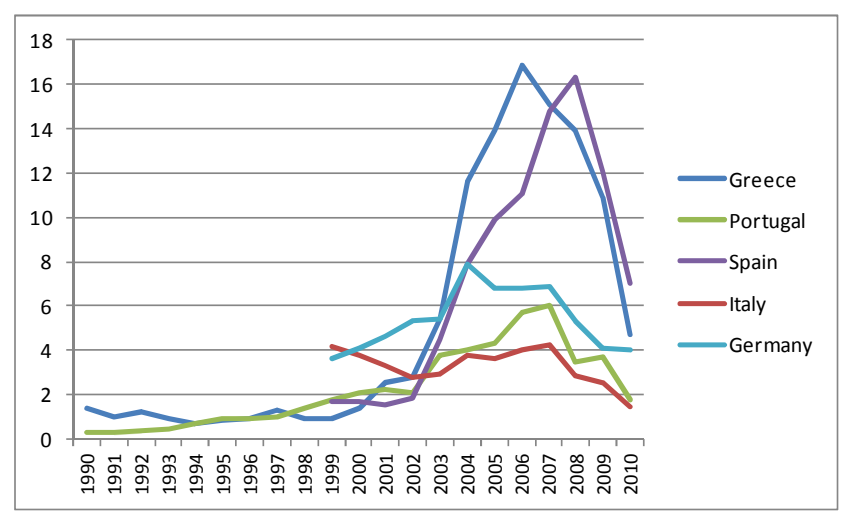

Source: Bank for International Settlements and World Bank

Figure 1. Short Term External Debt / Foreign Exchange Reserve (Absolute annual rates).

In the Figure 1, the moral hazard index shows that the surge of the over indebtedness was after the introduction of the Euro and accentuated around 2003. Paradoxically, these countries showed a transitory improvement. Furthermore, some governments were hiding information about the real situation. Greece and Spain have been the most profligates, they have not been provided a level of confidence to markets that their countries can meet their external financial obligations on time. At the same time the average annual growth rate of credit to private sector were the highest (2000-2011), more than 13 and 12 percent respectively (De Haan, 2012). However, if we include Germany, we notice that this country has been keeping a more stabilizing index in the 2000s. The financial situation of Ireland was more compelling, this indicator reached 500 times Figure 2. It showed the lack of interest by Irish authorities in maintaining its foreign currency liquidity to absorb external shocks, dealt with stoppages of external inflows, suddenly capital outflows or when the access to external borrowings will be scary, to cope effectively with possible financial crisis. One of the main causes in the Ireland's financial situation was the implicitly government guarantees for the six main banks, issuing special bonds by September 2008 and September 2009 to support them by removing their risk loans, especially from homeowners and property builders, who were over indebtedness under the boom of the real state sector and the access to low cost credits; in the context that the house prices in Ireland quadrupled between 1996 and 2007 (Whelan, 2011).

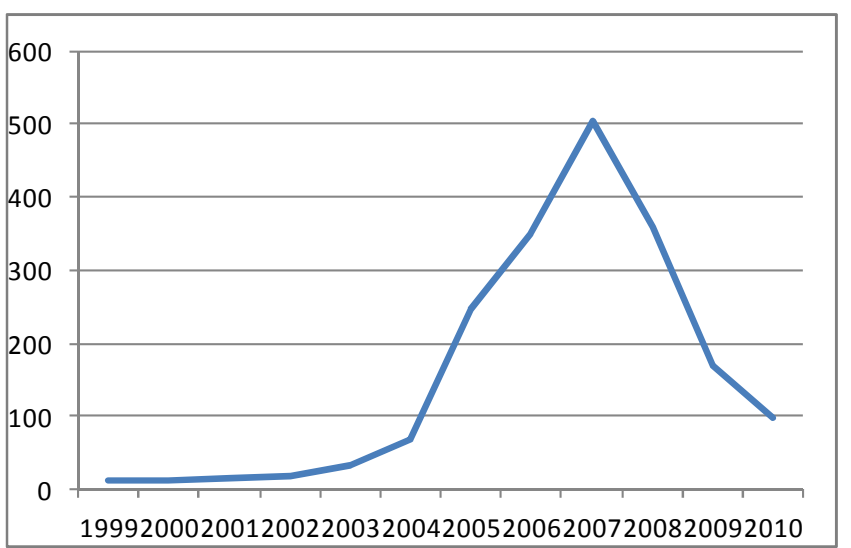

Source: Bank for International Settlements and World Bank

Figure 2. Irish Short Term External Debt / Foreign Exchange Reserve (Absolute annual rates).

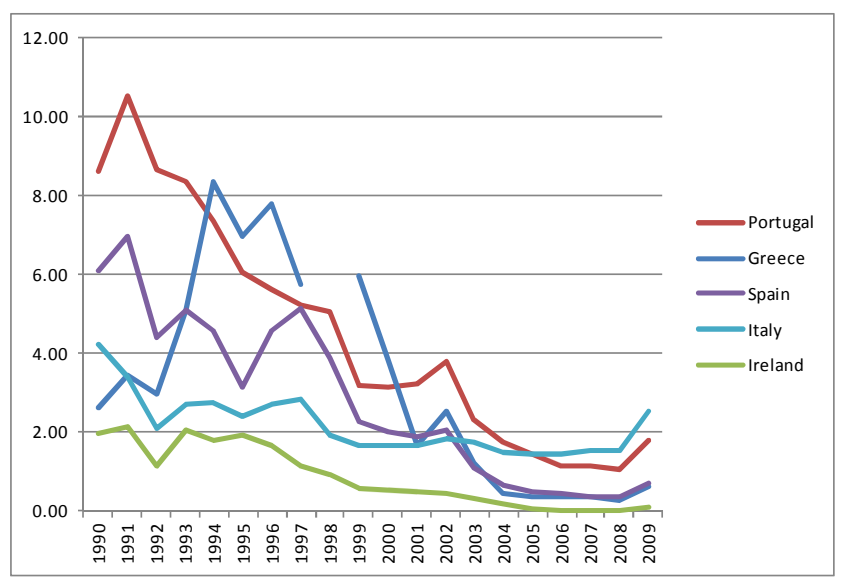

Source: World Bank

Figure 3. Total Foreign Exchange Reserves in Months of Imports (19902009).

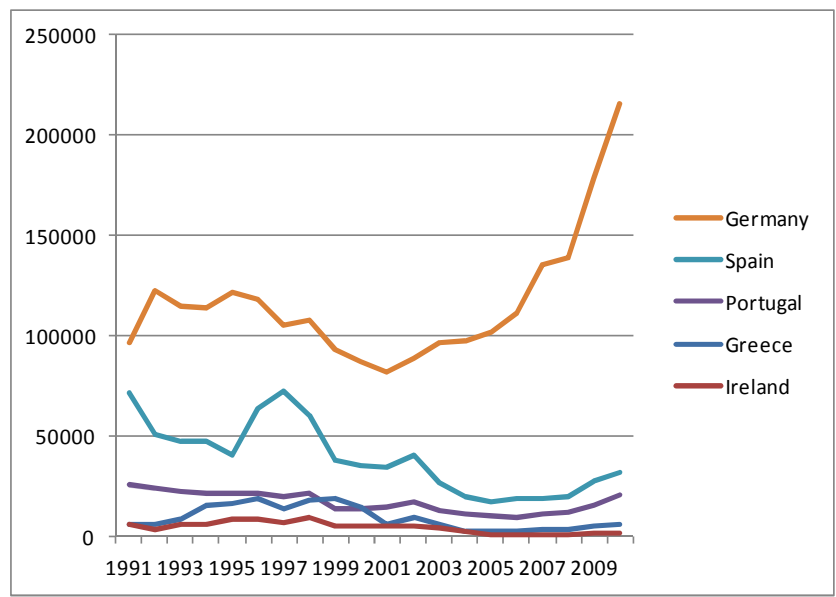

Source: World Bank

Figure 4. Total Foreign Exchange Reserves in US\$ million (1991-2010).

After collapsing the real state sector and becoming the banking crisis, the government decided to nationalize some banks and recapitalized others; the average annual growth rate of credit to private sector between 2000 and 2011 was more than 11 percent (De Haan, 2012). It is also fair to 
point out that the increasing of the Irish public spending was the highest, presented a structural deficit. Consequently, the annual growth of government expenditure in Ireland has been higher than Spain, Greece, Italy and Portugal, led to be unsustainable the government $\mathrm{debt}^{28}$. The rescue of the Ireland hugely expanded financial sector cost around 13.9 percent of $\mathrm{GDP}^{29}$, the Irish banks lost more than $€ 100$ billion because of defaulted loans to property developers and homeowners made real state or property bubble burst, along with unemployment increased and loosing of competitiveness in the private sector, austerity and deficit in the public sector. So, Irish banks lent money building owners, which in turn generated a real state bubble, loss of competitiveness and also a detriment in the trading sectors. The average annual growth rate of credit to private sector has been more than 11 percent between 2000 and 2011 (De Haan, 2012). Later, some executives of the principal Irish banks were obligated to resign, contributing to financial panic and increasing the long-term government bond yield spreads regarding core countries.

\subsection{Foreign Exchange Reserve Disappeared}

The Foreign Exchange Reserves to deal with financial disequilibrium decreased in these Western countries in the last decade, after the introduction of the Euro. Undoubtedly, this can be understand as the disinterest of governments to complying with creditors, repaying their Debts, dealing with external liabilities and international shocks and manipulates their domestic currency (Euro), to protect their international commercial and financial operations. Additionally, high Foreign Exchange Reserve allows countries getting better credit ratings by international grading agencies and less cost in their international finance operations and access to financing. The Table 2 showed the average Foreign Exchange Reserves in months of imports for different periods (lustrums), Greece, Portugal, Ireland, Italy and Spain were profligate with this variable; dramatically decreased in months of imports. In the case of Greece, since 5.44 months of imports in the $1990 \mathrm{~s}$, felt toward less than one month in the 2005-09s, in average. Portugal, since 6.88 months in the $1990 \mathrm{~s}$, felt towards 1.32 months in the last $2000 \mathrm{~s}$. Spain, since 4.62 months in the $1990 \mathrm{~s}$, felt toward 0.49 month in the $2000 \mathrm{~s}^{30}$. Ireland, since 1.82 months in the $1990 \mathrm{~s}$, felt toward less than 5 percent of one month in the $2000 \mathrm{~s}$.

28 Some authors said that in the case of Debt with the rest of the world, the most dramatic case was Ireland which moved from a net creditor position of 52 percent of the GDP in 1999 to a net debtor position of 71 per cent of the GDP in 2008 (De Haan, 2012).

29 Dadush, Uri and Stancil, Bennett (2010). Europe's Debt Crisis: More than a Fiscal Problem.

30 This compelling situation has originated by the end of April 2012, Standard and Poor's Rating Agency downgraded Spain in two levels, reaching the category of $\mathrm{BBB}^{+}$, in negative perspective; because of there existed the risk that the government support banks and increase its Public Debt.
Table 2. Simple Annual Average of Foreign Exchange Reserves in Months of Import of good and services (1990-2009).

\begin{tabular}{lllll}
\hline & $\mathbf{1 9 9 0 - 9 4}$ & $\mathbf{1 9 9 5 - 9 9}$ & $\mathbf{2 0 0 0 - 0 4}$ & $\mathbf{2 0 0 5 - 0 9}$ \\
\hline USA & 2.42 & 1.45 & 1.06 & 1.21 \\
Creece & 4.50 & 6.62 & 1.95 & 0.40 \\
Portugal & 8.72 & 5.04 & 2.85 & 1.32 \\
Ireland & 1.82 & 1.25 & 0.40 & 0.05 \\
Italy & 3.02 & 2.32 & 1.69 & 1.71 \\
Spain & 5.44 & 3.81 & 1.55 & 0.49 \\
\hline
\end{tabular}

Source: World Bank

This international financial situation could be seen again as a result of the moral hazard, because by issuing Euros as international reserve and transactional currency they could have been helped to finance their own imports of goods and services from third countries, especially from developing ones which their domestic currencies are not considered international reserve. Moreover, because of the accumulation of high Foreign Exchange Reserve allows countries the possibility to repaid their External Debts and liabilities, we can understand that they have been not willing to fulfill external creditors on time; furthermore, dealing with the sudden stoppages of capital inflows or outflows. In absolute terms (Figure 4) we can see how the Foreign Exchange Reserves have been quickly reduced in these periphery countries, while in Germany increased. On the other hand, nowadays developing countries as East Asian and Latin American, after suffering financial crisis have been disciplinary maintained high Foreign Exchange Reserves in the last years. For example, Chile, Peru, China and Korea, their current stock of Foreign Exchange Reserves can finance more than ten months of imports. Let us not forget that monetary authorities keep up with Foreign Exchange Reserves with the aim to finance external imbalances, avoiding adjust dramatically their economy activity. In the Fixed Exchange Rate regimen Central Banks maintain Foreign Reserves even if not to neutralize the operations of automatic mechanism (Ossa, 1997). The optimum average amount of FERs is determined by the need to reach an optimal combination between the external adjustment and financing in these countries; and the benefits are given by the avoided economic adjustment cost.

\subsection{Huge Fiscal Imbalances}

The result of the Public Finance, Table 3, showed that these countries did not have disciplinary managed their fiscal operations, living the governments beyond their own means. Additionally, after introducing Euro and reduction of the interest rate, having access to a cheap credit, "the per capita employee compensation (average wage) rose by an annual average of 5.9 percent (included private and public sectors) in these PIIGS countries, faster than North countries with only 3.2 percent. Furthermore, the increase in the periphery was not matched by improvements in labor productivity" (Dadush and Stancil, 2010); loosing international competitiveness. 
Table 3. Annual Average of General Government Deficit/Surplus (\% GDP).

\begin{tabular}{llll}
\hline & $\mathbf{1 9 9 5 - 9 9}$ & $\mathbf{2 0 0 0 - 0 5}$ & $\mathbf{2 0 0 6 - 1 0}$ \\
\hline Belgium & -2.44 & -0.47 & -2.28 \\
France & -3.44 & -2.78 & -4.58 \\
Greece & & -5.22 & -9.68 \\
Ireland & 0.82 & 1.45 & -9.96 \\
Italy & -4.34 & -3.08 & -3.54 \\
Portugal & -3.82 & -3.73 & -6.14 \\
Spain & -4.18 & -0.12 & -4.14 \\
\hline
\end{tabular}

Source: European Commission-Eurostat

Periphery countries maintained high Fiscal Deficits in the second lustrum of 2000 s, in spite of the fact that they had been getting a sporadic and short reduction only in the first 2000 years, just after introducing the Euro, and also as a result of one "Maastricht Treaty" restriction (1992) and then in the "Stability and Growth Pact" (1997). This policy was adopted in order to reduce their Fiscal Budget Deficits ceiling of less than 3 percent of GDP and their External Debt ceiling of less than 60 percent of GDP; as well as acknowledging the inherent risk of crisis due to the fact that the introduction of the new common currency in this very heterogeneous economically speaking European commercial block (Sandoval, Bertrand, and others, 2011) ${ }^{31}$. However, it seems that these restrictions were taken into consideration by policymakers only in this small period because later, in the 2006-10 years the Fiscal Deficits were dramatically increased; especially, in the cases of Ireland (reached 32 percent of the GDP in 2010), Greece, Portugal and Spain. On the other hand, Italy was maintained its Public Deficit at the same level and the core Euro-zone countries were reduced its Deficit showing less levels than the periphery, Germany reached only 1 percent of GDP in $2011^{32}$.

In the Figure 5, in the 2006-10 years the annual average Central Government Deficits increased in Ireland, Greece and Portugal regarding the five previous years. In the case of Portugal the highest public spends, among other causes, have been associated with the political situation and the Carnation Revolution (1974-2010). Therefore, the government was hazardously bolstered public-private partnerships, risky credits, external consultancy and private advisory for more than three decades. They were attempting to control the military insurgences in former Portugal colonies (provinces) in Africa, led increasing its military and administrative spends, with adverse impact in its public financial accounts. So, the boom associated with the Euro introduction, interest rate falling and private demand increasing period was short, losing competitiveness quicker than other periphery

31 Furthermore, they agreed greater coordination in monetary and economic policies from members of the Monetary Union, lowering the degree of national sovereignty and clout for certain member states. The Europe Sovereign Crisis (Sandoval, Bertrand, and other, 2011: 3).

32 In the last months these countries have made efforts in order to restore confidence, especially in the Fiscal scope strengthening the rules of budgetary discipline. This is why central bankers call upon the European governments to increase the emergency facility as soon as possible (De Haan, 2012). countries, with poor log-term growth prospect ${ }^{33}$.

Even though Portugal was doing better efforts than Greece in order to control its public finances, as well as reaching "Maastricht Treaty" indicators, it is unclear if really they (and other governments) reached reduction in their Public Debt in the first years of Euro currency introduction because there were some allegations of corruption and false public information in some periphery countries, especially in the case of Greece. For instance, the European Sovereign Debt Crisis began on October 2009, after announcing corruption behavior of the Greek First Minister George Papandreou at the Parliament; who said that the former government had been hidden real official information about its large Public Debt and Government Spending ${ }^{34}$.

Greece that historically has maintained compelling Public Debt problems, especially under having abundant access to cheap capital by joining to the Euro-zone in 2002, "there are several deeply entrenched features that created conditions for underlying the current financial crisis, chiefs among these are pervasive state control of the economy, a large and inefficient public administration, increased endemic tax evasion and reduce revenues to financing public spends; furthermore, government in this country has been very generous with public workers increasing their salaries and pensions and widespread political clientelism" (Nelson and other, 2010). Later the four principal commercial banks ${ }^{35}$ have been received financial support from the European Financial Stability Facility Fund.

In the case of Spain, its high Public Debt was caused basically by financial private sector, does not by the Public Sector, triggering the bubble of price in the real state. The Fiscal Deficits in these countries have been an indication that governments have been profligacy in maintaining sustainable Finance accounts, especially in the last 2000 years (Table 2). The behavior of the Public Debt-GDP ratio is one gauge of what is happening with the government finances, because of GDP is a rough measure of the government's tax base. An increasing of the Public Debt-GDP ratio can suggest that the government is living beyond their means (Graph $\mathrm{N}^{0}$ 5.6), as in Ireland, Portugal, Italy, Spain and Greece ${ }^{36}$, the government indebtedness is increasing relative its ability to raise tax revenue (Mankiw, 2001).

In Table 4 and Figure 6, we can see how the total Central Government Debt of these countries have been increasing in the 2000s, Greece and Portugal have been financed their spending with the support of domestic and external creditors, because their domestic Gross Saving rates have been small and decreasing, reaching in average only rates of 7.97 and

33 Ali, Shimelse (2010). Portugal's Growth Challenge. Paradigm Lost: The Euro in Crisis.

34 Claessens, Stinj and others 2011.

35 National Bank, Alpha, Eurobank and Piraeus Bank on May, 2012 received US\$ 22.5 billion, after losing around US\$ 28 billion in the re-scheduling of Greek debt in March.

36 February 2012 Greek government approved to reduce spends $€ 300$ million in pension cuts, 22 percent reduction in the minimum wage and cut the state sector workforce in 150,000 people by 2015 . This cut was needed to secure $€ 130$ billon second package of aid from Euro-zone finance ministers. 
11.30 percent of GDP in the last 2006-10s, see Table 5. Consequently, residents (government and private sectors) have resorted to borrowing from abroad creditors to finance their domestic investment and imports in the international markets, as we can see in the Current Account Deficit evaluation, Table 6 and Figure 7.

Table 4. Annual Average of Central Government Debt, Total (\% GDP).

\begin{tabular}{llll}
\hline & $\mathbf{1 9 9 5 - 9 9}$ & $\mathbf{2 0 0 0 - 0 4}$ & $\mathbf{2 0 0 5 - 0 9}$ \\
\hline Belgium & 118.62 & 100.13 & 87.57 \\
France & 60.78 & 64.47 & 72.40 \\
Greece & 109.17 & 125.61 & 129.03 \\
Ireland & 55.03 & 35.51 & 41.55 \\
Italy & 127.06 & 115.23 & 110.87 \\
Portugal & 60.95 & 62.71 & 72.96 \\
Spain & 63.92 & 52.39 & 36.59 \\
\hline
\end{tabular}

Source: World Bank

The increasing of the Public Debts in these countries have been through the emission of sophisticated financial instruments, we are coming from a world where financial innovation has been profoundly. It seems that it could not harm sometimes, hence should command a favorable predisposition from financial regulators in approval terms; which in turn led to be European countries almost impossible to repaying their increasing Public Debts obligations without bailout operations or the financial support from third parties such as European Central Bank (ECB) and/or International Monetary Fund (IMF), creating later a special fund called "European Financial Stability Facility" in May 2010. Let us not forget that one of the major benefits of joining Euro-zone was have access to greater liquidity and a lower cost of capital; therefore, for high indebted countries such Italy, Greece $^{37}$, Portugal, Spain and Belgium this means that they could borrow larger amounts at longer maturities and lower prices in "domestic currency" 38 .

In spite of creating European Financial Stability Facility (EFSF) funded with $€ 750$ billons, to support Sovereign Debt Crisis and reach financial stability around Euro-zone states by providing financial assistance ${ }^{39}$, the problems in these countries still without helpful solutions. So, later in October 2011 and February 2012, the Finance Ministers of the Euro region have joined in order to strengthen the EFSF fund, increasing in $€ 1$ Trillion to bolster financial situation of members especially Greece and Portugal. Furthermore, they were agreed to create Fiscal Union with strict fiscal rules, according to technical recommendations of specialists from different countries, with the aim to reduce concerns related investors about the ability of a country to implement fiscal consolidation ${ }^{40}$; however, the current situation in the

37 Italy did a better job than Greece of managing its fiscal affairs during the crisis, however its Public Debt as a percentage of the GDP is still higher than that of Greece (Dadush and Eidelman, 2010)

38 Jones, Erick (2011). "The Euro and the Financial Crisis".

39 For instance, recapitalize Banks or buying Sovereign Debt.

40 Rummel, Ole (2012). The Sovereign Debt Crisis: How to severe are the Challenges?
EMU shows us that while in the North (core) sub region countries are seem to convergence in terms of Deficit and Public Debt levels, in the periphery PIIGS the reality is very different between countries (at the same time, between these two economic European sub blocks).

\subsection{Savings, Investment and External Imbalances}

Greece has been the most profligacy country regarding savings, since having acceptable more that 20 percent of its GDP in 1990s as a National Saving rate, this country ends up in average with less than 8 percent in the last 2000s. In the case of Portugal, in the first half of the 1990 decade had more that 22 percent of its GDP as Gross National Saving by the end of the first 2000 decade, ends up with around 11 percent (2006-2010). Undoubtedly, both reductions have been as a consequence of facilities for easy access to foreign credits and reduction of interest rate in the 2000s, joining to the long run unsustainable welfare state policies. This compelling situation means that both countries were not been prepared to finance their domestic investment (public and private), as well as deal with financial crisis. On contrary, they have been requiring high external financing through negative Net Foreign Investment (NFI), accumulating Current Account Deficits and External liabilities (Table 6 and Figure 7).

Table 5. Simple Annual Average of Gross National Saving (\% GDP).

\begin{tabular}{lllll}
\hline & $\mathbf{1 9 9 1 - 9 5}$ & $\mathbf{1 9 9 6 - 2 0 0 0}$ & $\mathbf{2 0 0 1 - 0 5}$ & $\mathbf{2 0 0 6 - 1 0}$ \\
\hline Belgium & & & 24.68 & 23.86 \\
France & 21.75 & 20.56 & 19.88 & 19.30 \\
Greece & 22.08 & 17.15 & 14.32 & 7.97 \\
Ireland & 22.10 & 26.31 & 25.25 & 17.32 \\
Italy & 21.99 & 21.43 & 20.29 & 18.02 \\
Portugal & 22.35 & 20.35 & 16.86 & 11.30 \\
Spain & 22.02 & 22.46 & 22.99 & 20.25 \\
\hline
\end{tabular}

Source: World Bank

To assess the possibility of financial crisis in advance is the Current Account of Balance of Payments (BoP), whose annual Deficits were compelling increased in the first decade of 2000s (Figure 7). The highest annual average rate increasing was Greece, from 6.79 to 12.47 percent of the GDP (5.68 percent of increasing), the focus of the crisis, followed by Spain (3.05 percent of increasing), Ireland (2.28 percent of increasing), Portugal (2.14 percent of increasing) and Italy (1.72 percent of increasing in their Deficits), between the first and the second lustrums of 2000s. According to the Warning Alert System (Zhuan and Dowling, 2002) estimated for 1997 Asian Financial Crisis, the Current Account and Capital Account (Balance of Payments) indicators are on average more reliable than other types of indicators in assessing vulnerability and increasing of the risk to financial crisis. In developing world Current Account Deficit (BoP) was presented in all financial crises (Briceño, 2003).

Also it is fair to point out that in the case of the United States of America the annual average of the Current Account Deficit is almost similar between these two 2000's sub- 
periods (lustrums), maybe because of the fact that U.S.A. Dollar has been using as: (i) reserve currency (store of value), (ii) international mean of payments and (iii) unit of account for a long time; before being in force the Euro currency (1999). Additionally, the highest productivity in this industrialized country allows it gaining long run sustainability in this external indicator.

Table 6. Simple Annual Average of the Current Account Balance Deficit (BOP, \% GDP).

\begin{tabular}{lllll}
\hline & $\mathbf{1 9 9 1 - 9 5}$ & $\mathbf{1 9 9 6 - 2 0 0 0}$ & $\mathbf{2 0 0 1 - 0 5}$ & $\mathbf{2 0 0 6 - 1 0}$ \\
\hline Greece & -1.31 & -4.06 & -6.79 & -12.47 \\
Ireland & 2.12 & 1.22 & -1.12 & -3.4 \\
Italy & -0.02 & 1.53 & -0.94 & -2.66 \\
Portugal & -0.62 & -7.03 & -8.74 & -10.88 \\
Spain & -1.95 & -1.73 & -4.66 & -7.68 \\
USA & -1.07 & -2.64 & -4.82 & -4.34 \\
\hline
\end{tabular}

Source: World Bank

It is possible that countries have external Deficits for some years to help them finance imports of capital goods and technology, especially for the tradable sectors, as exporting industries (including inputs), or/and imports of national substitute goods, but not always. This kind of persistent Deficit in industrialized European countries could be understood not only as a weak of one macro fundamentals as a result of the domestic demand increasing in no tradable sectors like the real state, but also as a part of the moral hazard problem resulted from having the possibility to issuing an international paying and reserve currency such as Dollars and Euros. So it is believed that periphery Euro-zone countries became careless ${ }^{41}$. Consequently, these Current Accounts Balance becoming deficit in some countries, and other deepened their deficits (since 1999-2000 years, like a break point), with the introduction of the Euro. Likewise, in accordance to basic macroeconomic identities and the Theory of Gaps of Hollis Chenery (1966), there is a clear relation between the behavior of these three economic variables, such as the increasing of the Government Balance Deficit, low Gross National Savings and the high Current Account Deficits of the Euro-zone periphery. As we can see, since the components of the Gross Domestic Product (GDP:Y) are the Consumption (C), Investment (I), Government purchases (G), and Net Exports (NX), Exports less Imports, we can get the follow economic identity:

$\mathrm{Y}=\mathrm{C}+\mathrm{I}+\mathrm{G}+\mathrm{XN}$, which can be rewrite:

$\mathrm{Y}-\mathrm{C}-\mathrm{G}=\mathrm{I}+\mathrm{XN}$, then, being $\mathrm{S}=\mathrm{Y}-\mathrm{C}-\mathrm{G}$

$\mathrm{S}=\mathrm{I}+\mathrm{XN}$; or $\mathrm{S}=\mathrm{I}+\mathrm{NFI}$

The Gross National Saving (S) must be enough to finance Domestic Investment (I) and Net Foreign Investment (NFI) equals the Net Exports (NX). However, in the cases of Greece and Portugal, Domestic Savings (S) dramatically

41 When Europe introduced the Euro in 1999, most of the political leaders, economist and bankers, thought that the Euro would become a competitor of the U.S.A. Dollar as a reserve currency and the financial obligation denominated in Euros would be trusted as much as those in the United States. Cavallo, D. Yale University lecture, 2011. decreased in the 2000s, the Public and Private Sectors were financing by negative NFI, equivalent to the Current Account Deficit (BoP), which in turn means a high accumulation of external liabilities (indebtedness) of these countries. Therefore, in the Figure 8 , we can see how the gap between Domestic Investment and National Saving has been financing by accumulating negative Net Foreign Investment in Greece. We can see changes in this economy (Greece) after 1999, the year of Euro introduction ${ }^{42}$, before Gross National Saving (GNS) and Domestic Investment or Gross Capital Formation (GKF) were very close; therefore, the negative Net Foreign Investment (NFI) or Current Account Deficit (CAD) was smaller. After 2000, the National Savings rate fallen compelling because the Government Budget Deficit (GBD) increasing, and because also the private saving felt.

The case of Portugal is similar Greece. It has been presented an increase in domestic spending and deteriorating the Current Account Balance. The excess of Gross Capital Formation (GKF) or Domestic Investment has been financed not only with accumulation of Current Account Deficits or negative Foreign External Investment since 1990s. Furthermore, between 1995 and 2000 the private saving dropped around 7 percent, while the investment increased; consequently, the gap has been expanding, Figure 9. In the 2000 s, the GKF and the GNS have been reduced at the first time. However, the level of the first was higher, therefore the gap continued, especially due to the increasing of the General Government Deficit, with the over bureaucratized civil service, unclear private-state partnership, which in turn fueled investment bubbles, etc. The Current Account Deficit was broader, soaring 10 percent of the GDP in the second lustrum of 2000 .

\subsection{Other Causes}

Another similar cause presented in the Europe Sovereign Debt Crisis, United States of America mortgage crisis and other financial has been the boom in the Real State sector supported irresponsible by the government, creating a bubble asset price. For instance, after breaking in the USA bubble in 2007 became the financial crisis. Consequently, the felt down of the asset prices and break up the bubble has been one of the main factors in the current financial crisis in developed countries (Allen and Carletti, 2009). It is also fair to point out that the dramatic artificially increased of the house prices index was presented in other European countries like Spain, Ireland, Iceland and United Kingdom.

For some authors, this situation could be seen as a result of the low interest rate policy adopted by the U.S.A. Federal Reserve and other Central Banks, after the collapsing of the technology stock bubble by the end of $1990 \mathrm{~s}^{43}$. In this way, the situation in Spain was more dramatic, construction sector value-added reached 17 percent of GDP, in ten years the

42 However, it is fair to point out that Greece joined Euro-zone recently in 2002. 43 Adrian and Shin (2009), Brunnermeier (2009), Greenlaw et al. (2008) and Taylor (2008). Cited in Allen and Carletti, 2009. 
Spanish housing prices more than doubled, reached a peak in 2006, the country started more homes than the United Kingdom, Germany, France and Italy combined (Dadush and Eildeman, 2010). The boom in this non trade sector led Spain increases the wages higher than other EU country, contributed to weak its productivity and loos of competitiveness.

\section{Concluding Remarks and Policy Implications}

The origins of the current financial crisis is in maintaining implicit and explicit government guarantees for some private financial institutions without deductibles, and the absence of suitable financial regulation, creating a vicious circle between Banking and Sovereign Debt Crises amid irresponsible political indecisions, originated moral hazard with overexposure to private credit default, irresponsible private borrowers, over expenditure; awkward and risky investments and consequently assets price bubble and other disequilibrium.

Periphery and core EU countries have had serious problems to reconciling asymmetric monetary, fiscal and external needs. Their efforts to prevent excessive Public Debt and avoid financial bailout were unsuccessful. These problems reduced the attractiveness of the Euro currency for (i) reserve asset, (ii) medium of exchange and/or (iii) unit of account in international transactions. Consequently, in the next years the US\$ will be strengthen and dominant foreign currency, preferred for global transactions and reserve asset. It has been estimated that around 85 percent of the Foreign Exchange transactions, 60 percent of official Foreign Exchange Reserve and the half of the Foreign Securities will be denominated in U.S.A Dollars (Glick, 2012).

Because of moral hazard has been one of the main factors the financial crisis, it is important to come up with the explicit prohibition for the Central Banks to rescue or bailout directly and discretionally commercial financial institutions without deductibles and punishments with the aim to internalize the risk cost. Past hyperinflation were originated mainly from Central Banks emissions to finance Governments (monetization of Fiscal Deficits). After that, governments prohibited to finance their budgets in the primary financial markets by Central Banks, disappearing hyperinflation. Moreover, Central Banks should not expect that credit rating Agencies (Moody's, Standard and Poor's and Fitch IBCA) evaluate their financial situation; it is important to prevent mistakes with more transparent Central Banks, Financial Regulators and Finance Ministries.

In order to mitigate possibilities of future financial crisis it is important that Micro and Macro Prudential Regulations have been institutionalized, according to intrinsic problems in international financial markets and the high volatility of capital inflows toward developing countries affected by global factors (especially, in the case of Short-term Capital flows) and domestic factors (especially, in the case of Long- term Capital flows). These economic policy tools have proved been effectively in order to avoid high volatility of capital inflows in emerging markets in the last years; furthermore, the grade of implementation should be according to financial instruments such as financial derivatives and participation of Short-term Capital inflows.

Another important lesson is one trivial, developing and/or small countries with open capital accounts need Float Exchange Rates. It is not convenient establishing hard fixing or attaching local currency to the Euro or U.S.\$., because these episodes have been proved overvaluations, losing competitiveness and reducing the trade activities and the Gross Domestic Product. Like nowadays in the cases of Latvia, Estonia and Lithuania which currencies were attached to the Euro. Last but not least, it is very important to keep up with legally independent and technical Central Banks, far from politician influences, increasing their accountability and reduce their discretionarily intervention.

All in all, future research of the financial crises should be focused on moral hazard problems rather that in traditional weak fundamentals; consequently, economy policymakers should come up with the possibility to explicitly and legally avoiding the direct and discretionary interventions of the Central Banks or Governments (Finance Ministers) with the aim to rescue or bailout broken financial institutions under socialization programs of their debts.

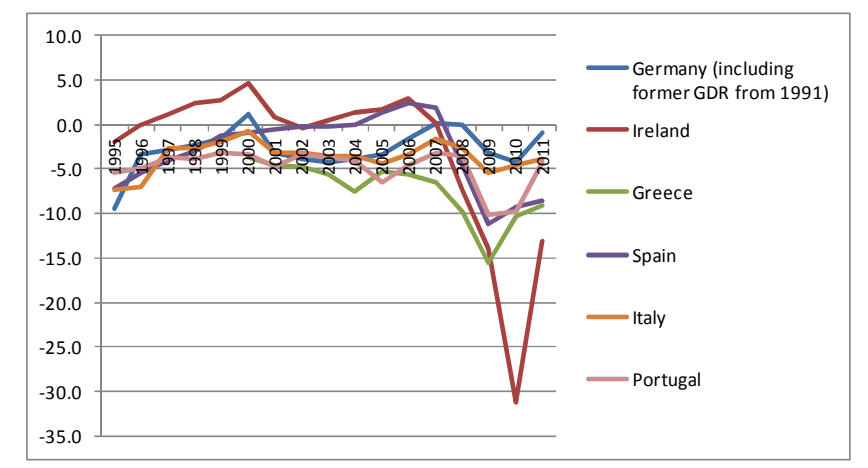

Source: European Commission-Eurostat

Figure 5. General Government Deficit/Surplus (\% GDP).

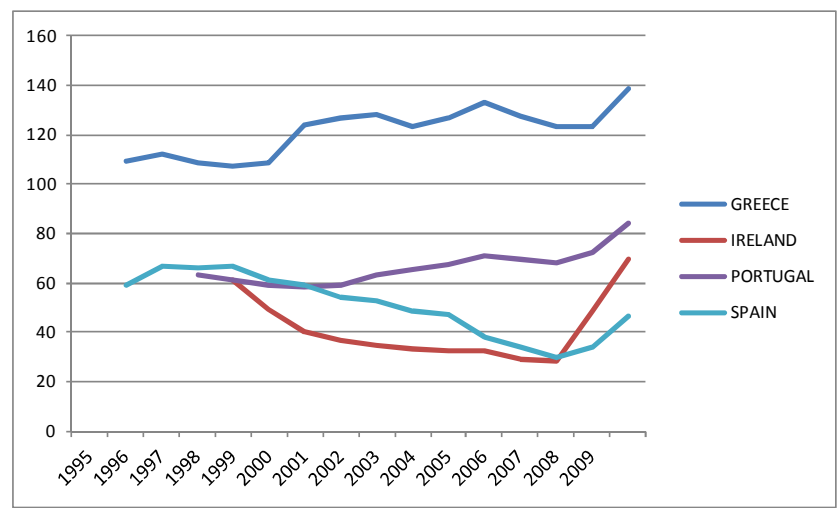

Source: World Bank

Figure 6. Central Government Debt, Total (\% of GDP). 


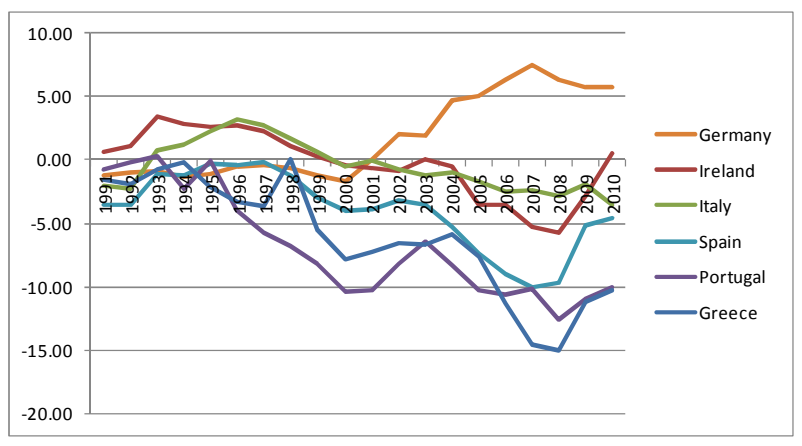

Source: World Bank

Figure 7. Current Account Balance (BOP, \% GDP).

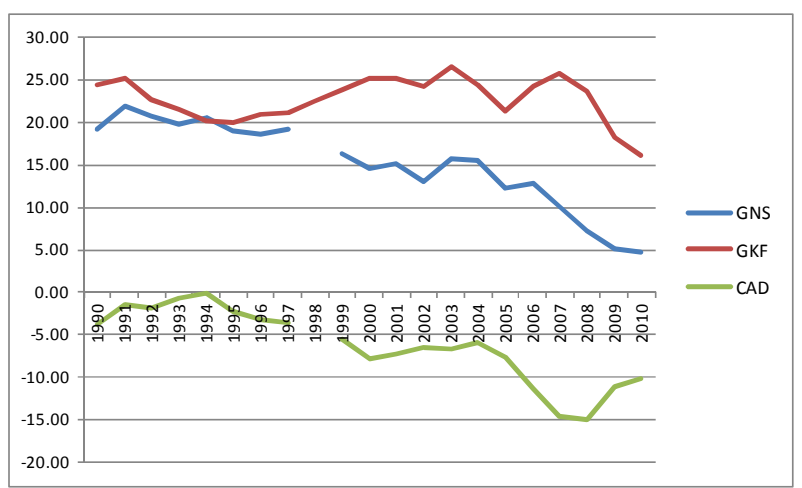

Sources: European Commission-Eurostat and World Bank

Figure 8. Greek Gross National Saving (GNS), Gross Capital Formation (GKF) and Current Account Deficit (CAD) as \% GDP.

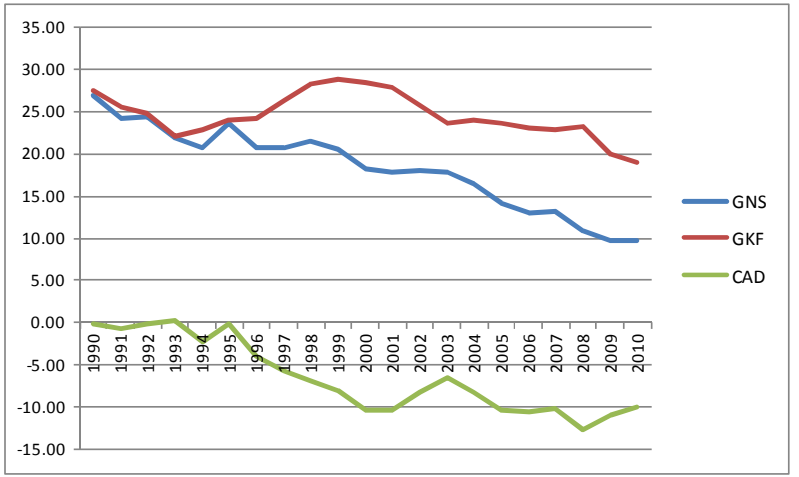

Source: European Commission-Eurostat and World Bank

Figure 9. Portuguese Gross National Saving (GNS), Gross Capital Formation (GKF) and Current Account Deficit (CAD) as \% GDP.

\section{Acknowledgement}

This is part of my thesis to get the Master Degree in International Development Studies in Hankuk University of Foreign Studies, Seoul, South Korea (2011-2012). I would like to thank professors Won-Ho Kim for being my thesis advisor and Mason Richey for his comments. Furthermore, World Bank Institute (WBI) and Korean Development Institute School (KDI) that allowed me participate in the Senior Policy Seminar "Managing Capital Flows and Growth: Amid the Sovereign Crisis", Seoul, June 4-7, 2012. Also I am indebtedness with Professor Alain Jousten from
Maastricht University, for his feedback and comments.

\section{References}

[1] Akerlof, George A. (Aug., 1970). The Market for Lemons: Quality Uncertainty and the Market Mechanism. The Quarterly Journal of Economics, Vol. 84, No 3: 485-500.

[2] Allen, Franklin and Carletti, Elena. (2009) The Global Financial Crisis: Causes and Consequences. University of Pennsylvania. Working paper.

[3] Briceño Avalos, Hernán Ricardo (2003). Tipo de Cambio Cuasi-fijo y Posibilidad de Crisis Cambiarias: Solarizar o Dolarizar la Economía Peruana? Working paper.

[4] Claessens, Stijn; Tong, Hui and Zuccardi, Igor (September, 2011). Did the Euro Crisis Affect Non-Financing Firm Stock Prices through a Financial or Trade Channel? International Monetary Fund, Working Paper.

[5] Chang, Roberto (Aug., 2011). The Global Crisis and the Future of the Central Banks. Rutgers University. Peruvian Reserve Central Bank presentation.

[6] Dadush, Uri; Aleksashennko, Sergey and other (2010). Paradigm Lost: The Euro in Crisis. Carnegie Endowment for International Pace. Washington DC.

[7] Delimatsis, Panagiotis and Sauvé, Pierre (2011). Financial Services Trade after the Crisis: Policy and Legal Conjectures. Journal of International Economic Law 13 (3): 837-857.

[8] De Haan, Jakob (May, 2012). The Future of European Monetary Union. Maastricht University Forum.

[9] De Paula, Luis Fernando and Alves, Antonio J. (2003). Baking Behavior and the Brazilian Economy After the Real Plan a Post Keynesian Approach.

[10] De Soto, Hernando. Who Owns This Mess? International Herald Tribune. Dec. 02, 2011. http://www.nytimes.com/2011/12/02/opinion/magazineglobal-agenda-who-owns-this-mess.html?pagewanted=all

[11] Diamond DW, Dybvig PH (1983). Bank runs, deposit insurance, and liquidity. Journal of Political Economy 91 (3): 401-419.

[12] Feldstein, Martin. The Political Economy of the European Economic and Monetary Union: Politicas Sources of an Economic Liabilities. NBER Working Paper series. 1996.

[13] Franco, Gustavo (1995). The Real Plan. Working paper presented at Seminar "Economics and Society in Brazil: New trends and perspectives". Chicago.

[14] Gil-Diaz, Francisco (1997). The Origin's of Mexico 1994 Financial Crisis. The Cato Journal. Vol. 17. $\mathrm{N}^{\mathrm{o}} 3$. http://www.cato.org/pubs/journal/cj17n3-14.html.

[15] Gruben, William and Kiser, Cherry (1999). Brazil the First Financial Crisis of 1999. Southwest Economy, Federal Reserve Bank of Dallas.

[16] Hillman, Robert W. (1992). "Limited Liability and Externalization of Risk: A. Comment on the Death of Partnership”. 70 Washington University Law Quarterly 477. 
[17] Holman, Jill A. (2001). Is the Large U.S. Current Account Deficit Sustainable? Federal Reserve Bank of Kansas City. Economic Review. First Quarterly.

[18] Hornbeck, J. F. (June, 2000). The Argentine Financial Crisis, a Chronological of Events.

[19] Jehle, Geoffrey and Reny, Philip (2000). Advanced Microeconomic Theory. Second Edition. The Addison-Wesley Series in Economics.

[20] International Monetary Fund (2004). Guidelines for Foreign Exchange Reserve Management. Washington D.C.

[21] Jones, Erick (2009). The Euro and the Financial Crisis. Survival, Vol. 51, No 2, April - May 1999. Pp. 41-54.

[22] Licona Michel, Angel (Dec., 2011). Política Económica y Crecimiento en México: Cinco sexenios en búsqueda de la estabilidad. International Conference: "Rethinking SocioEconomic Transformation in Latin America". Seoul, South Korea.

[23] Mankiw, Gregory (2001). Principles of Economics. Second edition. Harcourt College Publishers.

[24] Michael Bailey and Heinz Stecher (2000). Working paper. Oxfam GB.

[25] Misekell, Raymond and Zinser, James (1973). The Nature of the Savings Function in Developing Countries: A Survey of the Theoretical and Empirical Literature. American Economic Association. Journal of Economic Literature, Volume 11, No 1. Pp. 1-26.

[26] Mundell, Robert (1961). A Theory of Optimum Currency Area. The American Economic Review. Vol. 51, No. 4, (Sep. 1961), pp. 657-665.

[27] Nelson, Rebecca; Belkin, Paul, and Mix, Derek (August, 2011). Greece's Debt Crisis: Overview, Policy Responses, and Implications. Congressional Research Services.

i Luis Donaldo Colosio from the Partido Revolucionario Institucional (PRI) was killed in March 23, few days before Presidential election. Later was elected Ernesto Zedillo, August 21th., 1994.

ii http://www.cato.org/pubs/journal/cj17n3-14.html

iii The financial crisis was caused by lack of supervision, but not by the adaptation of Washington Consensus recommendations.

iv Larraín, Felipe. y Vergara, Rodrigo. "La Transformación Económica de Chile", Centro de Estudios Públicos (CEP). Chile, 2000.
[28] Ossa Scaglia, Fernando (1997). "Some extensions: Tariffs, Power Parity Purchase and Exchange Policy". Economía Monetaria Internacional. VI Chapter. Pontifical Catholic University of Chile. Second edition. Santiago, Chile. Pp. 213242. http://www.fas.org/sgp/crs/row/R41167.pdf

[29] Radelet, Steven and Sachs, Jeffrey (1998). The Onset of the Asian Financial Crisis. Working paper. Harvard Institute for International Development.

[30] Rothschild, Michael and Stiglitz, Joseph (Nov., 1976). "Equilibrium in Competitive Insurance Market: An essay on the Economics of Imperfect Information". The Quarterly Journal of Economics. Volume 90. $\mathrm{N}^{\mathrm{o}}$ 4: 629-649.

[31] Sandoval, Lazaro; Beltran, Erika; Ulziikhutag, Sodgerel, and Zorigt, Temuun (2011). "The European Sovereign Debt Crisis: Responses to the Financial Crisis". George Mason University. New Voice in Public Policy. Volume V. Spring 2011.

[32] United Nations Conference on Trade and Development and the United Nations Economic Commission for Europe (Oct., 1998). Working paper. Geneva. http://www.twnside.org.sg/title/1998-cn.htm

[33] Varian, Hall (2010). Intermediate Microeconomic: A modern approach. University of California at Berkeley. Eight edition.

[34] World Bank. Global Development Debate. What are the Development Challenges in a Post Crisis World? Jun., 2010. http://developmentdebates.ning.com/group/developmentdebat es

[35] World Bank Institute (October, 2010). Global Development Debate. How to Manage Capital Flows. http://developmentdebates.ning.com/page/globaldevelopment-debate-on

[36] Zewuster, Marijke (May, 2012). Country Risk and European Debt Crisis. Maastricht University Forum.

[37] Zhuang, Juzhong and Dowling, Malcolm (Oct., 2002). Financial Crisis: What can an Early Warning System Model Tell us? Asian Development Bank. 